\title{
The effects of water potential on some active forms of phosphorus in a calcareous soil amended with sewage sludge
}

* ALI AKBAR SAFARI SINEGANI; ALI MAHOHI

\author{
${ }^{l}$ Associate Professor, Department of soil science, College of Agriculture, Bu-Ali Sina University, Hamedan, Iran. \\ Email:aa-safari@basu.ac.ir \\ ${ }^{2}$ MSc student, Department of soil science, College of Agriculture, Bu-Ali Sina University, Hamedan, Iran.
}

\begin{abstract}
Immobilization and mobilization reactions of soil phosphorus depend on biological properties of soil and these soil properties strongly depend on the soil water potential. The objective of this study was to test the effects of water potential on some active forms of soil P. A semiarid soil classified as Calcic Haploxerept was treated with raw sewage sludge at a rate of $20 \mathrm{~g} \mathrm{~kg}^{-1}$. Water potentials established for soil incubation were: saturation (SA, 0 bar), field capacity (FC, -0.3 bar), and permanent wilting point (PWP, -15 bar). An irrigation treatment was dryingrewetting cycle (DWC) between -0.3 to -15 bars. After 0, 20, 60 and 90 days of incubation soils were sampled for analysis. The addition of sewage sludge increased soil total $\mathrm{P}$, organic $\mathrm{P}$, available $\mathrm{P}$, microbial $\mathrm{P}$, soluble and easily soluble $\mathrm{P}$ contents. The increase of soluble $\mathrm{P}$ was relatively higher. The effects of soil moisture, incubation time and their interaction on all active forms of soil $\mathrm{P}$ were significant. During 20 days of incubation, available $\mathrm{P}$ and soluble $\mathrm{P}$ decreased, whereas microbial $\mathrm{P}$, easily soluble $\mathrm{P}$ and dicalcium phosphate increased significantly. After that, available $\mathrm{P}$ and easily soluble $\mathrm{P}$ increased continuously, but microbial $\mathrm{P}$, soluble $\mathrm{P}$ and dicalcium phosphate fluctuated during incubation. Microbial $\mathrm{P}$ had negative and significant correlations with available $\mathrm{P}$ and easily soluble P. Soils incubated in DWC and FC compared to soils incubated in SA and PWP had significantly higher available P, soluble $\mathrm{P}$ and easily soluble $\mathrm{P}$ contents. However microbial $\mathrm{P}$ and dicalcium phosphate were significantly higher in soils incubated in higher water potential. @ JASEM
\end{abstract}

The use of wastes, such as sewage sludge, in agriculture and for land reclamation is increasingly being identified as an important issue for soil conservation in semi-arid climate zones (Navas et al., 1998; Ros et al., 2003). The influence of sewage sludge on soil physical and chemical properties is well known. Sewage sludge addition has been shown to produce beneficial changes including increases in organic matter, organic carbon, major nutrients (e.g., $\mathrm{N}, \mathrm{P}$ ), water-holding capacity and porosity of soils (Logan et al., 1997; Navas et al., 1998; Ku"tu"k et al., 2003). Phosphorus (P) is an important macronutrient that constitutes vital molecules such as nucleic acid, phospholipids and sugar phosphates in all living organisms. It makes up about $0.2 \%$ of plant dry weight. Terrestrial plants generally meet their $\mathrm{P}$ requirement by the uptake of soil $\mathrm{P}$ in inorganic form (Marschner, 1995). Bicarbonate-extraction is amongst the most common soil-test $\mathrm{P}$ methods. Typically available $P$ represents between 1 and $5 \%$ of the total soil P. This operationally defined extraction technique was originally developed for the estimation of plant-available soil $\mathrm{P}$, and is commonly used as an index of soil $\mathrm{P}$ status, to determine fertilizer $\mathrm{P}$ requirements (Kamprath and Watson, 1980). Phosphorus availability may be the most limiting factor to plant growth in many terrestrial ecosystems (Chapin et al., 1994). For soils rich in $\mathrm{CaCO}_{3}$, the solubility of $\mathrm{P}$ is primarily dominated by the solid phase dicalcium phosphate or chemisorption of $\mathrm{P}$ on calcite, with the formation of a surface complex of calcium carbonate-P with a defined chemical composition (Von Wandruszka, 2006). Ion exchange between $\mathrm{P}$ and carbonate minerals and the precipitation of phosphate with calcium significantly limit the $\mathrm{P}$ availability in desert soils. Competition of organic anions for adsorption sites on calcite also increases the availability of $\mathrm{P}$ in the soil solution (Holford et al., 1990).

Between 30 and $50 \%$ of total soil $\mathrm{P}$ is composed of organic $\mathrm{P}$, which occurs mainly as phytates, nucleic acids (and their derivatives) and phospholipids (Paul and Clark, 1989). A major constituent of organic P in soil is phytate (inositol hexa- and penta-phosphates), which can account for up to half of the total organic $P$ present. Mineral orthophosphate $\left(\mathrm{PO}_{4}{ }^{-3}\right)$ is the sole form of $\mathrm{P}$ assimilated by microorganisms and plants. Orthophosphate ions are released in soil and litter solutions as a consequence of mineralization of organic phosphorus (Rao et al., 1996). P mineralization is usually positively correlated with residue $\mathrm{P}$ concentration and negatively correlated with $\mathrm{C} / \mathrm{P}$ ratio and lignin concentration or lignin/ $\mathrm{P}$ ratio (Lupwayi and Haque, 1999; Kwabiah et al., 2003). Changes in both soil moisture and temperature influence microbial activity and thereby affect $\mathrm{P}$ mineralization (Kabba and Aulakh, 2004). There is also growing evidence that soil biological properties are very affected by environmental factors and may be potential indicators of ecological stress (Dick and Tabatabai, 1992). Other factors as increases in salinity (Rietz and Haynes, 2003) or decreases in water availability may also reduce microbial activity (Mamilov and Dilly, 2002). Turner and Haygarth (2003), reported that soil drying causes significant changes in water-extractable $\mathrm{P}$, in particular organic $\mathrm{P}$, and that these changes appeared to be related to direct $\mathrm{P}$ release from lysed microbial cells. The

\footnotetext{
* Corresponding author: * Ali Akbar Safari Sinegani
} 
response of organically amended soils to wet/dry cycles using incubation experiments have been studied by several researchers (Magid et al., 1999; Mamilov and Dilly, 2002). In most of these studies it was focused on organic matter turnover and $\mathrm{N}$ transformations by measuring soil respiration rates, microbial biomass carbon, $\mathrm{N}$ mineralization and nitrification (Thomsen et al., 1999; Salamanca et al., 2003; Zaman and Chang, 2004). Bioavailable P from organic manures is mainly in the dissolved form. It occupies only a small fraction of total $\mathrm{P}$ and particulate organic $\mathrm{P}$ is a major fraction of total $\mathrm{P}$. Although organic forms of phosphorus (P) play an important role in the biological availability of soil $\mathrm{P}$, the concentrations, forms, and dynamics of $\mathrm{P}$ in soil are poorly understood. There is not much information about the effects of water potential on $\mathrm{P}$ active forms after soil treatment with organic wastes. The objective of this study was to investigate the effects of soil water potential on P mineralization and some active forms of $\mathrm{P}$ in a calcareous soil amended with sewage sludge.

\section{MATERIALS AND METHODS Soil and organic waste sampling}

The soil classified as Calcic Haploxerept (Soil Survey Staff, 1998), was sampled from the top $20-\mathrm{cm}$ layer of an agricultural land in Hamadan, in northwest of Iran, with semi-arid climate (annual rainfall of $300 \mathrm{~mm}$; annual average temperature 13 ${ }^{\circ} \mathrm{C}$ ). Raw sewage sludge was sampled from Serkan Wastewater Plant, which processes domestic wastewater.

\section{Soil physical and chemical analyses}

Air-dry soil was subsequently crushed and sieved to pass a $2-\mathrm{mm}$ mesh screen for particle-size analysis using the hydrometer method (Gee \& Bauder, 1986). Equivalent calcium carbonate (ECC) was measured by back titration procedure (Leoppert. \& Suarez, 1996). Soil pH and electrical conductivity (EC) were measured in a 1:5 soil: water extract after shaking for 30 min (Hesse, 1971). Organic carbon (OC) was analyzed by dichromate oxidation and titration with ferrous ammonium sulfate (Walkley \& Black, 1934). Total nitrogen in all samples was determined by the Kjeldahl method (Hinds \& Lowe, 1980). Different forms of soil $\mathrm{P}$ including total $\mathrm{P}$, organic $\mathrm{P}$, available $\mathrm{P}$, easily soluble $\mathrm{P}$ and dicalcium phosphatehosphate were extracted by percholoric-nitric acid, sulfuric acid, $0.5 \mathrm{M} \mathrm{NaHCO}_{3}, 1 \mathrm{M} \mathrm{NH} \mathrm{NH}_{4} \mathrm{Cl}$ and $0.25 \mathrm{M}$ $\mathrm{NaHCO}_{3}$ respectively, and determined spectrophotometrically as blue molybdate-phosphate complexes under partial reduction with ascorbic acid (Chang and Jackson, 1957; Jackson,1958; Sommers and Nelson.1972; Bowman,1989; Jiang and $\mathrm{Gu}, 1989$ ).

\footnotetext{
* Corresponding author: * Ali Akbar Safari Sinegani
}

\section{Microbiological and biochemical analyses}

Fresh soil samples were stored at $4{ }^{\circ} \mathrm{C}$ for microbiological analyses. We determined microbial biomass $\mathrm{P}$ (MBP) in each sample using $\mathrm{CHCl}_{3}$ as a biocide, and bicarbonate as an extractant (Brookes et al., 1982; Hedley and Stewart, 1982). The difference between $\mathrm{Pi}$ in nonbiocide-treated samples and $\mathrm{Pm}+\mathrm{Pi}$ in biocide-treated samples was considered to be Pm. Sewage sludge was also analyzed according to those methods.

\section{Incubation procedure}

The sampled soil was treated with sewage sludge (SS), at a rate of $20 \mathrm{~g} \mathrm{~kg}^{-1}$ (dry weight basis). Four levels of irrigation (with deionized water) were established for 90 days. Soil moistures were maintained at: saturation (Sat, 0 bar), field capacity (FC, -0.3 bar), and permanent wilting point (PWP, 15 bar). An irrigation treatment was drying-rewetting cycle (DWC) between -0.3 to -15 bars. After 0,20 , 60 and 90 days of incubation a portion of each soil were taken for analysis. Different forms of soil $\mathrm{P}$ including available $\mathrm{P}$, microbial $\mathrm{P}$, soluble $\mathrm{P}$, easily soluble $\mathrm{P}$ and dicalcium phosphatehosphate were analyzed according to the methods mentioned above. Analysis of soil P forms in DWC treatment carried out at 48 hours after soil rewetting. Soil moisture was near field capacity at this time.

\section{Statistical analyses}

Data were statistically analyzed for standard deviation, means were calculated, and Duncan's new multiple range tests were performed to assess the effect of organic amendments and soil water potential on the active forms of phosphorus. The computer programs used for data analysis were Ms-Excel and SAS 6. SPSS 6.0 for windows (spss Inc).

\section{RESULTS}

\section{Chemical properties}

Table 1 shows some sewage sludge properties used in this study. Sewage sludge EC was relatively high. The addition of sewage sludge to soil increased soil $\mathrm{EC}$ and decreased soil $\mathrm{pH}$. Soil treatment with sewage sludge increased soil organic $\mathrm{C}$, total $\mathrm{N}$ and $\mathrm{P}$ contents significantly (Table 2). The increase of organic $\mathrm{C}$ was 1.48 times. Changes in total $\mathrm{N}$ content were similar to those obtained for organic $\mathrm{C}$. Total $\mathrm{P}$ was increased from 2.03 to $2.64 \mathrm{~g} \mathrm{~kg}^{-1}$. Soil organic $\mathrm{P}$, available $\mathrm{P}$, microbial $\mathrm{P}$, soluble and easily soluble $P$ contents were also increased after addition of sewage sludge to soil. The increase of soluble $\mathrm{P}$ was relatively higher. It was 3.51 times of untreated soil. Whereas the increase in easily soluble $\mathrm{P}$ was lower. It was only 1.07 times of untreated soil.

Table 3 shows analysis of variance of sewage sludge treated soil available P, microbial P, soluble P, easily 
soluble $\mathrm{P}$ and dicalcium phosphate contents as affected by soil moisture (SM) and incubation time (IT). Soil moisture, incubation time and their interaction had strongly significant effects on all of those properties $(\mathrm{p}<0.001)$. The effects of soil moisture compared to the effects of incubation time (mean squares) on available $\mathrm{P}$, microbial $\mathrm{P}$ and soluble $\mathrm{P}$ were relatively lower. However the effects of soil moisture compared to the effects of incubation time on easily soluble $\mathrm{P}$ and dicalcium phosphate were relatively higher. These may be related to the rate of reactions of different forms of $\mathrm{P}$ in soil. The reaction rate of easily soluble $\mathrm{P}$ and dicalcium phosphate in soil may be slower than the reaction rate of available $\mathrm{P}$, microbial $\mathrm{P}$ and soluble $\mathrm{P}$.

Table 1: Some sewage sludge characteristics applied in soil.

\begin{tabular}{ll}
\hline Properties & mean \\
\hline $\mathrm{pH}(1: 5)$ & 7.50 \\
Electrical conductivity $\left(\mathrm{dS} \cdot \mathrm{m}^{-1}\right)$ & 4.600 \\
Total organic carbon $\left(\mathrm{g} \cdot \mathrm{kg}^{-1}\right)$ & 570.0 \\
Total N $\left(\mathrm{g} \cdot \mathrm{kg}^{-1}\right)$ & 57.30 \\
Total P $\left(\mathrm{g} \cdot \mathrm{kg}^{-1}\right)$ & 30.07 \\
$\mathrm{C} / \mathrm{N}$ & 9.95 \\
$\mathrm{C} / \mathrm{P}$ & 18.57 \\
\hline
\end{tabular}

Table 2: Some soil characteristics before and after treatment with sewage sludge

\begin{tabular}{|c|c|c|c|}
\hline Soil properties & $\begin{array}{l}\text { Before } \\
\text { treatment }\end{array}$ & $\begin{array}{l}\text { After } \\
\text { treatment }\end{array}$ & $\begin{array}{l}\text { Increase } \\
\text { ratio }\end{array}$ \\
\hline $\mathrm{pH}(1: 5)$ & 7.95 & 7.64 & 0.96 \\
\hline EC $\left(\mathrm{dS} . \mathrm{m}^{1}\right)$ & 0.142 & 0.232 & 1.63 \\
\hline Organic C (g. $\left.\mathrm{kg}^{1}\right)$ & 21.4 & 31.57 & 1.48 \\
\hline Total N (g. $\left.\mathrm{kg}^{1}\right)$ & 3.94 & 4.64 & 1.18 \\
\hline Total P $\left(\mathrm{g} \cdot \mathrm{kg}^{1}\right)$ & 2.03 & 2.64 & 1.3 \\
\hline Organic $\mathrm{P} \quad\left(\mathrm{g} \cdot \mathrm{kg}^{-1}\right)$ & 0.799 & 0.885 & 1.11 \\
\hline Available P (mg.kg $\left.{ }^{1}\right)$ & 25.27 & 36.52 & 1.45 \\
\hline Microbial P (mg.kg $\left.{ }^{1}\right)$ & 21.23 & 42.55 & 2 \\
\hline Soluble $\mathrm{P}\left(\mathrm{mg} \cdot \mathrm{kg}^{1}\right)$ & 3.24 & 11.39 & 3.51 \\
\hline Easily soluble $\mathrm{P}\left(\mathrm{mg} \cdot \mathrm{kg}^{1}\right)$ & 10.07 & 10.82 & 1.07 \\
\hline Dicalcium phosphate (mg. $\left.\mathrm{kg}^{1}\right)$ & 33.98 & 37.78 & 1.11 \\
\hline $\mathrm{C} / \mathrm{N}$ & 5.31 & 6.8 & 1.28 \\
\hline $\mathrm{C} / \mathrm{P}$ & 10.54 & 11.96 & 1.13 \\
\hline Equivalent calcium carbonate $(\%)$ & 3.55 & & \\
\hline Sand $(\%)$ & 63.5 & & \\
\hline Silt $(\%)$ & 20.6 & & \\
\hline Clay (\%) & 15.9 & & \\
\hline
\end{tabular}

Table3: Analysis of variance (mean square) of sewage sludge treated soil available $\mathrm{P}$, microbial $\mathrm{P}$, soluble $\mathrm{P}$, easily soluble $\mathrm{P}$ and dicalcium phosphate as affected by soil moisture (SM) and incubation time (IT) ${ }^{\#}$.

\begin{tabular}{lllllll}
\hline $\begin{array}{l}\text { Source of } \\
\text { variations }\end{array}$ & Df & Available P & Microbial P & Soluble P & Easily soluble P & Dicalcium phosphate \\
\hline SM & 3 & $231.125^{* * *}$ & $193.838^{* * *}$ & $96.235^{* * *}$ & $478.906^{* * *}$ & $345.126^{* * *}$ \\
IT & 3 & $2355.829^{* * *}$ & $3242.605^{* * *}$ & $127.270^{* * *}$ & $454.620^{* * *}$ & $320.918^{* * *}$ \\
SM*IT & 9 & $185.471^{* * *}$ & $8083298^{* * *}$ & $52.492^{* * *}$ & $182.602^{* * *}$ & $170.119^{* * *}$ \\
\hline
\end{tabular}

\# Mean squares marked by *, ** and *** are significant at $\mathrm{P}<0.05, \mathrm{P}<0.01$ and $\mathrm{P}<0.001$, respectively.

\section{The effects of soil moisture}

Table 4 shows the effects of soil moisture on available $\mathrm{P}$, microbial $\mathrm{P}$, soluble $\mathrm{P}$, easily soluble $\mathrm{P}$ and dicalcium phosphate contents of the sewage sludge treated soil. Soils incubated in DWC and FC compared to those incubated in SA and PWP had higher available $\mathrm{P}$ contents. The differences between available $\mathrm{P}$ in soils incubated in $\mathrm{DWC}, \mathrm{FC}$ and $\mathrm{SA}$ were not significant $(\mathrm{p}<0.05)$. However, available $\mathrm{P}$ in soil incubated in PWP was significantly lower than those incubated in other moistures. Microbial $\mathrm{P}$ in soils incubated in different moisture conditions was significantly different. It was significantly higher in soil incubated in SA condition (38.686 mg kg-1). Microbial P in soils incubated in DWC and FC were not significantly different. The lowest microbial $\mathrm{P}$ was measured in soil incubated in PWP $(28.871 \mathrm{mg}$ $\mathrm{kg}^{-1}$ ). Soil incubation in different moistures had significantly different soluble $\mathrm{P}$. Soluble $\mathrm{P}$ was higher in soil incubated in FC compared to those incubated in other moistures. The differences between soluble $\mathrm{P}$ in soils incubated in DWC, FC were not significant $(p<0.05)$. Soluble $P$ in soil incubated in FC and DWC was significantly higher than in soil incubated in FC and PWP. The lowest soluble $\mathrm{P}$ was measured in soil incubated in PWP (3.706 mg kg-1). Easily soluble $P$ in soils incubated in different moisture conditions was significantly different. Same as available $\mathrm{P}$ and soluble $\mathrm{P}$, easily soluble $\mathrm{P}$ was significantly higher in soil incubated in FC condition (24.415 $\mathrm{mg} \mathrm{kg}^{-1}$ ). Soil incubation in SA decreased easily soluble $\mathrm{P}$ significantly. The lowest easily soluble $\mathrm{P}$ was measured in soil incubated in SA (9.382 $\mathrm{mg} \mathrm{kg}^{-1}$ ).

Dicalcium phosphate in soils incubated in different moisture conditions was significantly different. Same as microbial $\mathrm{P}$, dicalcium phosphate was higher in soil incubated in SA compared to those incubated in other moistures $\left(43.486 \mathrm{mg} \mathrm{kg}{ }^{-1}\right)$. The lowest 
dicalcium phosphate was measured in soil incubated $\quad$ in PWP (30.914 $\left.\mathrm{mg} \mathrm{kg}^{-1}\right)$

Table 4: Available $\mathrm{P}$, microbial $\mathrm{P}$, soluble $\mathrm{P}$, easily soluble $\mathrm{P}$ and dicalcium phosphate contents in sewage sludge treated soils incubated in different moistures $\#$.

\begin{tabular}{|c|c|c|c|c|c|}
\hline Soil moisture & $\begin{array}{c}\text { Available P } \\
\left(\mathrm{mg}^{\mathrm{kgg}}{ }^{-1}\right)\end{array}$ & $\begin{array}{c}\text { Microbial P } \\
\left(\mathrm{mg} \cdot \mathrm{kg}^{-1}\right)\end{array}$ & $\begin{array}{l}\text { Soluble P } \\
\left(\mathrm{mg} \cdot \mathrm{kg}^{-1}\right)\end{array}$ & $\begin{array}{c}\text { Easily Soluble P } \\
\left(\mathrm{mg} \cdot \mathrm{kg}^{-1}\right)\end{array}$ & $\begin{array}{c}\text { Dicalcium } \\
\text { phosphate (mg.kg } \\
1 \text { ) }\end{array}$ \\
\hline DWC & $47.992^{\mathrm{a}}$ & $33.979^{b}$ & $8.969^{\mathrm{a}}$ & $18.520^{b}$ & $40.481^{b}$ \\
\hline PWP & $38.858^{\mathrm{b}}$ & $28.871^{\mathrm{c}}$ & $3.706^{\mathrm{c}}$ & $14.863^{\mathrm{c}}$ & $30.914^{d}$ \\
\hline FC & $47.832^{\mathrm{a}}$ & $33.244^{\mathrm{b}}$ & $9.550^{\mathrm{a}}$ & $24.415^{\mathrm{a}}$ & $37.969^{\mathrm{c}}$ \\
\hline SA & $46.931^{\mathrm{a}}$ & $38.686^{\mathrm{a}}$ & $5.302^{\mathrm{b}}$ & $9.382^{\mathrm{d}}$ & $43.486^{\mathrm{a}}$ \\
\hline
\end{tabular}

\# Values followed by the same letter in each column are not significantly different $(\mathrm{P}<0.05)$.

\#\# DWC- drying-rewetting cycle (between -0.3 to -15 bar), PWP- permanent wilting point ( -15 bar), FC- field capacity ( -0.3 bar), SAsaturation (0 bar).

Table 5: Soil available $P$, microbial $P$, soluble $P$, easily soluble $P$ and dicalcium phosphate contents in different incubation times ${ }^{\#}$.

\begin{tabular}{lccccc}
\hline $\begin{array}{l}\text { incubation } \\
\text { time (days) }\end{array}$ & $\begin{array}{c}\text { Available P } \\
\left(\mathrm{mg} \cdot \mathrm{kg}^{-1}\right)\end{array}$ & $\begin{array}{c}\text { Microbial P } \\
\left(\mathrm{mg} \cdot \mathrm{kg}^{-1}\right)\end{array}$ & $\begin{array}{c}\text { Soluble P } \\
\left(\mathrm{mg}^{-1} \mathrm{~kg}^{-1}\right)\end{array}$ & $\begin{array}{c}\text { Easily Soluble P } \\
\left(\mathrm{mg}^{\left.-1 g^{-1}\right)}\right.\end{array}$ & $\begin{array}{c}\text { Dicalcium } \\
\text { phosphate }\left(\mathrm{mg} \cdot \mathrm{kg}^{-}\right.\end{array}$ \\
\hline 0 & $36.524^{\mathrm{c}}$ & $42.552^{\mathrm{b}}$ & $11.394^{\mathrm{a}}$ & $10.817^{\mathrm{d}}$ & $37.776^{\mathrm{c}}$ \\
20 & $32.092^{\mathrm{d}}$ & $52.142^{\mathrm{a}}$ & $4.548^{\mathrm{c}}$ & $12.857^{\mathrm{c}}$ & $40.254^{\mathrm{b}}$ \\
60 & $49.913^{\mathrm{b}}$ & $16.946^{\mathrm{d}}$ & $7.548^{\mathrm{b}}$ & $19.177^{\mathrm{b}}$ & $31.303^{\mathrm{d}}$ \\
90 & $63.084^{\mathrm{a}}$ & $23.141^{\mathrm{c}}$ & $4.431^{\mathrm{c}}$ & $24.328^{\mathrm{a}}$ & $43.516^{\mathrm{a}}$ \\
\hline
\end{tabular}

\# Values followed by the same letter in each column are not significantly different $(\mathrm{P}<0.05)$.

Table 6: Pearson correlation coefficients between available $\mathrm{P}$, microbial $\mathrm{P}$, soluble $\mathrm{P}$, easily soluble $\mathrm{P}$ and dicalcium phosphate in sewage sludge treated soil $(\mathrm{n}=48)^{\#}$

$\begin{array}{llccc}\text { Available } P & \text { Microbial } p & \text { Soluble } P & \begin{array}{c}\text { Easily } \\ \text { soluble } P\end{array} & \begin{array}{c}\text { Dicalcium } \\ \text { phosphate }\end{array}\end{array}$

\begin{tabular}{|c|c|c|c|c|c|}
\hline Available P & 1 & & & & \\
\hline Microbial $\mathrm{p}$ & $-0.589^{* * *}$ & 1 & & & \\
\hline Soluble P & $0.144^{\mathrm{ns}}$ & $-0.047^{\mathrm{ns}}$ & 1 & & \\
\hline Easily soluble P & $0.595^{* * *}$ & $-0.576^{* *}$ & $0.224^{\mathrm{ns}}$ & 1 & \\
\hline Dicalcium phosphate & $0.341^{*}$ & $0.256^{\mathrm{ns}}$ & $0.005^{\mathrm{ns}}$ & $-0.0116^{\mathrm{ns}}$ & 1 \\
\hline
\end{tabular}

\section{The effects of incubation time}

Table 5 shows the effects of incubation time on soil available $\mathrm{P}$, microbial $\mathrm{P}$, easily soluble and dicalcium phosphate contents. Soil available $\mathrm{P}$ significantly decreased from $36.524 \mathrm{mg} \mathrm{kg}^{-1}$ to $32.092 \mathrm{mg} \mathrm{kg}^{-1}$ in 20 days of incubation in sewage sludge treated soil. It may be related to increase of microbial population and $\mathrm{P}$ immobilization. After 20 days of incubation available $P$ increased up to 49.913 and $63.084 \mathrm{mg} \mathrm{kg}^{-}$ ${ }^{1}$ in 60 and 90 days of incubation respectively. The differences between available $\mathrm{P}$ in different time of soil incubation were significant $(p<0.05)$. Microbial $\mathrm{P}$ was also different in different time of incubation. The highest microbial $P$ was measured after 20 days of incubation. Microbial P significantly increased from $42.552 \mathrm{mg} \mathrm{kg}^{-1}$ to $52.142 \mathrm{mg} \mathrm{kg}^{-1}$ in 20 days of incubation and then decreased to $16.946 \mathrm{mg} \mathrm{kg}^{-1}$ in 60 days of incubation. Microbial $\mathrm{P}$ once again increased to $23.141 \mathrm{mg} \mathrm{kg}^{-1}$ in 90 days of incubation. These changes may be due to temporal variability of microbial populations in soil. Same as available P, soluble $\mathrm{P}$ decreased from 11.394 to $4.548 \mathrm{mg} \mathrm{kg}^{-1}$ in 20 days of incubation then it increased up to 7.548 $\mathrm{mg} \mathrm{kg}{ }^{-1}$ in 60 days of incubation. Soluble $\mathrm{P}$ once again decreased to $4.431 \mathrm{mg} \mathrm{kg}^{-1}$ in 90 days of incubation. The differences between soluble $\mathrm{P}$ in soils incubated in 20 and 90 days of incubation were not significant $(\mathrm{p}<0.05)$.

The differences between easily soluble $\mathrm{P}$ in different time of incubation were significant at 0.05 level. Easily soluble $\mathrm{P}$ increased continuously during soil incubation. It rose up from $10.817 \mathrm{mg} \mathrm{kg}^{-1}$ to 12.857 , 19.177 and $24.328 \mathrm{mg} \mathrm{kg}^{-1}$ in 20,60 and 90 days of incubation respectively. It may be a good index for $\mathrm{P}$ mineralization in soil. Dicalcium phosphate was also different in different time of incubation. Same as

* Corresponding author: * Ali Akbar Safari Sinegani 
microbial $\mathrm{P}$, it fluctuated during incubation. Dicalcium phosphate significantly increased from $37.776 \mathrm{mg} \mathrm{kg}^{-1}$ to $40.254 \mathrm{mg} \mathrm{kg}^{-1}$ in 20 days of incubation and then decreased to $31.516 \mathrm{mg} \mathrm{kg}^{-1}$ in 60 days of incubation. Dicalcium once again increased to $43.516 \mathrm{mg} \mathrm{kg}^{-1}$ in 90 days of incubation.

\section{Correlation analysis}

Correlation coefficient between soil available $\mathrm{P}$ and microbial $\mathrm{P}$ was negative and significant at 0.001 level. Whereas, soil available $\mathrm{P}$ had positive and significant correlations with easily soluble $\mathrm{P}(\mathrm{P}<0.01)$ and dicalcium phosphate $(\mathrm{P}<0.05)$. However the correlation of microbial $\mathrm{P}$ with soluble $\mathrm{P}$ was not significant (table 6). Microbial $\mathrm{P}$ had negative and insignificant correlations with soluble P. However the negative correlation between microbial $\mathrm{P}$ and easily soluble $\mathrm{P}$ was significant at 0.01 level. The correlation coefficient between microbial $\mathrm{P}$ and dicalcium phosphate was positive but it was not significant. Soil soluble $\mathrm{P}$ had positive but insignificant correlations with available and dicalcium phosphate. The correlation between dicalcium phosphate and easily soluble $\mathrm{P}$ was also insignificant.

\section{DISCUSSION}

This study showed that total $\mathrm{P}$, organic $\mathrm{P}$, available $\mathrm{P}$, microbial $\mathrm{P}$, soluble $\mathrm{P}$, easily soluble $\mathrm{P}$ and dicalcium phosphate contents of soil increased by addition of sewage sludge. The increase of soil soluble $\mathrm{P}$ and biomass $\mathrm{P}$, were more obvious. Other researchers also reported that short-term application of organic wastes in soil caused an increase in available $\mathrm{P}$ (Lehmann et al, 2005). It was suggested that treatment of soils with animal manure, not only increased the available nutrient in soil, but also affected soil microbial biomass. Addition of organic wastes to soil improved the generation and activities microbial biomass (Martens, 2000). The added organic waste promotes biological and microbial activities, which accelerate the breakdown of organic substances in the added waste to soil (Agbenin and Goladi, 1998). The results showed that all $\mathrm{P}$ forms in soil were severely affected by soil water potential. The highest soil available $\mathrm{P}$ were obtained for soils incubated in FC and DWC and the lowest available P was measured in soil incubated in PWP. These finding may be related to microbial activity and populations. It was reported that soil drying reduces microbial activity and mineralization of organic $\mathrm{C}, \mathrm{N}$ and $\mathrm{P}$, decreases microbial mobility and restricts substrate and nutrient availability (West et al, 1992; Pulleman and Tietema, 1999). According to Magid et al (1999), microorganisms lose some of their ability to degrade complex substrates during desiccation. In constant moisture regimes, microorganisms was

\footnotetext{
* Corresponding author: * Ali Akbar Safari Sinegani
}

adapted to water conditions and showed the highest activities. The highest and the lowest microbial $\mathrm{P}$ were measured in soils incubated in SA and PWP. However available $\mathrm{P}$ and soluble $\mathrm{P}$ were relatively higher in soil incubated in drying and rewetting condition. Mikhaa et al (2005) reported that repeated dry-rewetting cycle's, did not significantly reduce the size of the microbial biomass. Therefore, the size of microbial biomass was not the limiting factor for $\mathrm{N}$, C and P mineralization. Turner and Haygarth (2003), reported that soil drying causes significant changes in water-extractable $P$, and that these changes appeared to be related to direct $\mathrm{P}$ release from lysed microbial cells. Similar changes were reported for inorganic P in bicarbonate extracts of New Zealand pasture soils, and resin extracts of a range of mainly low organic matter soils (Olsen and Court, 1982).

It was reported that seasonal changes in bicarbonateextractable inorganic and organic $\mathrm{P}$ in sandy Danish soils were far greater than those expected on the basis of biological processes alone. Microbial cell death during the drying and rewetting process is primarily induced by osmotic shock and cell rupture upon rewetting with a solution of low ionic strength. Therefore, the high ionic strength of bicarbonate solution may reduce this effect compared with water extraction (Kieft et al., 1987; Magid and Nielsen, 1992). In this study soluble $P$ compared to other forms of $\mathrm{P}$ was relatively high in soil incubated in DWC. Result showed that all studied forms of soil $\mathrm{P}$ were affected by incubation time significantly. The first decrease of available $P$ and increase of microbial $P$ in 20 days of incubation may be due to increase of soil microbial population and immobilization of inorganic soil P. Wong et al (1998), reported that available $\mathrm{P}$ in sewage sludge treated soil decreased significantly 28 days after soil treatment. Microbial $\mathrm{P}$ had negative and significant correlations with available $P$ and easily soluble $P$. After 20 days of incubation microbial $\mathrm{P}$ decreased, whereas available $\mathrm{P}$ and easily soluble $\mathrm{P}$ increased continuously due to microbial autolysis and $\mathrm{P}$ mineralization because of the reduction of easily degradable materials (Yan et al, 2000) and the induction of unfavorability of soil for microbial populations (Bardgett et al, 1999).

\section{REFERENCES}

Agbenin, J.O.; Goladi, J.T., (1998). Dynamics of phosphorus fractions in a savanna Alfisol under continuous cultivation. Soil Use Manage. 14: 59-64.

Bardgett. R.D.; Lovell, R.D.; Hobbs, P.J.; Javis, S.C., (1999). Seasonal change in soil microbial communities along a fertility gradient of temperature grasslands. Soil Biol. Biochem. 31: 1021- 1030. 
Bowman, R.A., (1989). A Sequential Extraction procedures with concentrated sulfuric acid and dilute base for soil organic phosphorus. Soil Sci. Soc. Am. J. 53: 366-382.

Brookes, P.C.; Powlson, D.S.; Jenkinson, D.S., (1982). Measurement of soil microbial biomass. Soil Biol. Biochem. 16: 169- 175.

Chang, S.C.; Jackson, M.L., (1957). Fractionation of soil phosphorus. Soil Sci. 84: 133-144.

Chapin, F.S.; Walker, L.R.; Fastie, C.L.; Sharman, L.C., (1994). Mechanisms of primary succession following deglaciation at Glacier Bay, Alaska. Ecological Monographs 64: 149-175.

Dick, W.A.; Tabatabai, M.A., (1992). Significance and potential uses of soil enzymes. In: Blain, F.J. (Ed.), Soil Microbial Ecology Application in Agricultural and Environmental Management. Marcel Dekker, New York, 95-127.

Gee, G.W.; Bauder, J.W., (1986). Particle size analysis. In: Klute A. (ed),.Method of soil analysis, part 1: Physical and mineralogical methods. Soil Sci. Soc. Am. Madison, Wisconsin USA. 383-411.

Griffin, D.M., (1981). Water potential as a selective factor in the microbial ecology of soil. In: Parr, J.F.; Gardner, W.R.; Elliott, L.F. (Eds.), Water Potential Relations in Soil Microbiology. Soil Sci. Soc. Am. Madison, WI, 141-151.

Hedley, M.J.; Stewart, J.W.B., (1982). Method to measure microbial phosphate in soil. Soil Biol. Biochem. 14: 377-385.

Hesse, P.R., (1971). A text book of soil chemical analysis. John Murray. London

Hinds, A.; Lowe, L.E., (1980). Ammonium-N determination. Soil nitrogen. Berthelot reaction. Soil Sci. Plant An. 11: 469-475.

Holford, I.C.R.; Chater, M.; Mattingly, G.E.G., (1990). Effects of decalcification on the phosphate sorption characteristics of eight calcareous soils, Aust. J. Soil Res. 28: 919-928.

Jackson, M.L., (1958). Soil Chemical Analysis. Prentice Hall, Englewood Cliffs, NJ.
Jiang, B.; Gu, Y., (1989). A suggested fractionation scheme for inorganic phosphorus in calcareous soil's. Fertility Resource. 20: 159- 165.

Kabba, B.S.; Aulakh, M.S., (2004). Climatic conditions and crop residue quality differentially affect $\mathrm{N}, \mathrm{P}$, and $\mathrm{S}$ mineralization in soils with contrasting P status. J. Plant Nutr. Soil Sci. 167: 596-601.

Kamprath, E.J.; Watson, W.E., (1980). Conventional soil and tissue tests for assessing the phosphorus status of soils. p. 433-469. In F.E. Khasawneh et al. (ed.) The role of phosphorus in agriculture. ASA, CSSA, and SSSA, Madison, WI.

Kieft, T.L.; Soroker, E.; Firestone, M.K., (1987). Microbial biomass response to a rapid increase in water potential when dry soil is wetted. Soil Biol. Biochem. 19: 119-126.

Ku"tu"k, C.; Cayci, G.; Baran, A.; Bas_kan, O.; Hartmann, R., (2003). Effects of beer factory sludge on soil properties and growth of sugar beet (Beta vulgaris saccharifera L.). Biore. Tech. 90: 75-80.

Kwabiah, A.B.; Palm, C.A.; Stoskopf, N.C.; Voroney, R.P., (2003). Response of soil microbial biomass dynamics to quality of plant materials with emphasis on $\mathrm{P}$ availability. Soil Biol. Biochem. 35: 207-216.

Leoppert, R.H.; Suarez, G.L., (1996). Carbonates and Gypsum. In: Sparks D.L. (ed.) Methods of soil analysis. Part 3, Chemical methods. Madison, Wisconsin, USA.

Logan, T.J.; Lindsay, B.J.; Goins, L.E.; Ryan, J.A., (1997). Field assessment of sludge metal bioavailability to crops: sludge rate response. J. Environ. Qual. 26: 534-550.

Lupwayi, N.Z.; Haque, I., (1999). Leucaena hedgerow intercropping and cattle manure application in the Ethiopian highlands. I. Decomposition and nutrient release. Biol. Fertil. Soils 28: 182-195.

Magid, J.; Kjærgaard, C.; Gorissen, A.; Kuikman, P.J., (1999). Drying and rewetting of a loamy sand soil did not increase the turnover of native organic matter, but retarded the decomposition of added 14C-labelled plant material. Soil Biol. Biochem. 31: 595-602.

Magid, J.; Nielsen, N.E., (1992). Seasonal variation in organic and inorganic phosphorus fractions of 
temprate-climate sandy soils. Plant Soil. 144: 155-165.

Mamilov, A.Sh.; Dilly, O.M., (2002). Soil microbial eco-physiology as affected by short-term variations in environmental conditions. Soil Biol. Biochem. 34: 1283-1290.

Marschner. H., (1995). Nutrient availability in soils, in: H. Marschner (Ed.), Mineral Nutrition of Higher Plants, Academic Press, London, 483507.

Martens, D.A., (2000). Plant residue biochemistry regulates soil carbon cycling and carbon sequestration. Soil Biol. Biochem. 32: 361-369.

Mikhaa, M. M.; Riceb, C.W.; Millikenc G.A., (2005). Carbon and nitrogen mineralization as affected by drying and wetting cycles. Soil Biol. Biochem. 37: 339-347

Navas, A.; Bermu'dez, F.; Maci'n, J., (1998). Influence of sewage sludge application on physical and chemical properties of Gypsisols. Geoderma. 87: 123-135.

Olsen, R.G.; Court, M.N., (1982). Effect of wetting and drying of soils on phosphate adsorption and resin extraction of soil phosphate. J. Soil Sci. 33: 709-717.

Paul, E.A.; Clark, F.E., (1989). Soil Microbiology and Biochemistry. Academic Press Inc. San Diego, CA

Pulleman, M.; Tietema, A., (1999). Microbial C and $\mathrm{N}$ transformations during drying and rewetting of coniferous forest floor material. Soil Biol. Biochem. 31: 275-285.

Rao, M.A.; Gianfreda, L.; Palmiero, F.; Violante, A., (1996). Interactions of acid phosphatase with clays, organic molecules and organo-minera complexes. Soil Sci. 161: 751-760.

Rietz, D.N.; Haynes, R.L., (2003). Effects of irrigation-induced salinity and sodicity on soil microbial activity. Soil Biol. Biochem. 35: 845854.

Ros, M.; Herna'ndez, M.T.; Garcı'a, C., (2003). Soil microbial activity after restoration of a semiarid soil by organic amendments. Soil Biol. Biochem. 35: 463-469.
Salamanca, E.F.; Kaneko, N.; Katagiri, S., (2003). Rainfall manipulation effects on litter decomposition and the microbial biomass of the forest floor. Appl. Soil Ecol. 22: 271-281.

Soil Survey Staff., (1998). Keys to soil taxonomy, eighth ed. USDA-NRCS Washington, DC.

Sommers, L.E.; Nelson,D.W., (1972). Determination of total Phosphorus I soil : A rapid percholoric acid digestion procedure . Soil Sci. Soc. Am. 36: 902904 .

Thomsen, I.K.; Schjønning, P.; Jensen, B.; Kristensen, K.; Christensen, B., (1999). Turnover of organic matter in differently textured soils. II. Microbial activity as influenced by soil water regimes. Geoderma 89: 199-218.

Turner, B.L.; Haygarth, P.M., (2003). Changes in Bicarbonate-extractable Inorganic and Organic Phosphorusby Drying Pasture Soils. Soil Sci. Soc. Am. 67: 344-350.

Von Wandruszka., R., (2006). Phosphorus retention in calcareous soils and the effect of organic matter on its mobility, Geochem. Tran. 7: 6-14.

Walkley, A.; Black, I.A., (1934). An examination of the Degtareff method for determining soil organic matter, and a proposed modification of the chromic acid titration method. Soil Sci. 37: 29-38.

West, A.W.; Sparling, G.P.; Feltham, G.W.; Reynolds, J., (1992). Microbial activity and survival in soil dried at different rates. Aust. J. Soil Res. 30: 209-222.

Wong, J.W.C.; Lai, K.M.; Fang, M.; Ma, K.K., (1998). Effect of sevage Sludge amendment on soil microbial activity and nutrient mineralization. Envi. Inter. 24: 935-943.

Yan, F.; McBratney, A.B.; Copeland, L., (2000). Functional substrate biodiversity of cultivated and uncultivated a horizons of vertisols in NWNew south Wales. Geoderma. 96: 321- 343.

Zaman, M.; Chang, S.X., (2004). Substrate type, temperature, and moisture content affect gross and net $\mathrm{N}$ mineralization and nitrification rates in agroforestry systems. Biol. Fertil. Soils. 39: 269279. 